\title{
The Role of NGOs in Financing Public Primary Education in Kenya
}

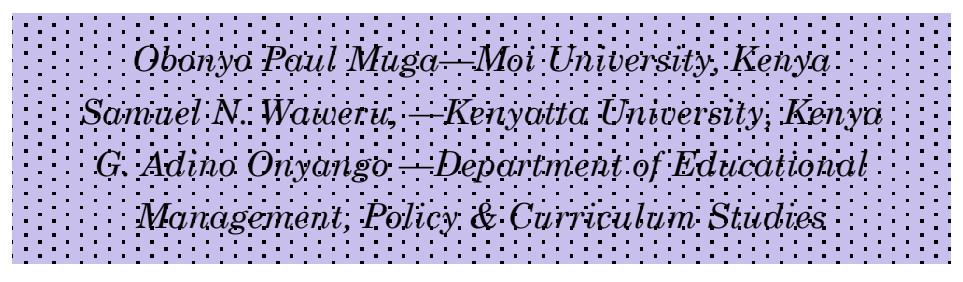

\section{Abstract}

The World Conference on Education for All, held in Jomtiem, Thailand 1990 stated that education is so diverse, complex and demanding to expect governments alone to meet the vast arrays of learner needs. The call for a multi-sectoral approach and building new alliances between governments, private, and NGOs forces was central to the thematic round tables on "NGOs and Literacy" and Mobilizing for "Education for All" (Hadaad 1990). This study examined the role of NGOs in financing public primary education in Budalangi, Kenya. The specific objectives of the study were: to determine NGOs participation areas in public primary education provision focusing on disbursement procedures and equity considerations for different socio-economic groups; to find out the various sources of NGOs' funds; to reveal the challenges facing NGOs in their effort to support public primary education and finally, to find out the adequacy and relevance of NGOs support as perceived by 
school heads, parents and pupils in the region. The study adopted a descriptive survey paradigm. The target population comprised of 16 NGOs supporting public primary education, 33 primary schools and 16518 pupils and their parents benefiting from NGOs support. The sample included nine NGOs, seven public primary schools and 111 pupils and their parents. This gave a total of 238 respondents. The data was collected using questionnaires for NGO administrators and head teachers and interview schedules for parents and pupils. The study found out that NGOs play a central role in promoting quality, access, equity and relevance of primary education by providing physical facilities, direct support to pupils and parents. It was noted that the number of supported pupils was significant (31\%) in relation to the total school enrolment. However, NGOs faced the challenge of insufficient funds, lack of exit strategy and mistrust by the government. The study recommends that the NGOs should use capacity building for sustained support and to work hand in hand with the government and all other stakeholders in education to help Kenya meet her international commitment in achieving the MDG goal in Education and EFA goals adopted in Dakar in 2000.

\section{Background to the Study}

Existing literature indicates that
communities and parents in Kenya, as in other


African countries meet a high percentage of the cost of education (Olembo, 1985). The Kenya government has been unable to fully provide free basic education to all eligible children. Despite the introduction of Free Primary Education (FPE) in 2003 which saw enrolment rise from 5.9 million in 2002 to 9.4 million in 2012, over one million children of school going age are still out of school (Standard, January 18, 2012).

GOs have been key partners in many countries in boosting limited state resources to achieve universal primary education and gender parity goals. The positive impacts of NGOs involvement in education provision can be seen in programmes supported by NGOs in Ethiopia, Ghana, Guinea, Mali, Southern Sudan and Uganda. In Southern Sudan, CARE's work in sensitizing communities about sending children to school is reported to have increased girls' enrolment by $96 \%$. Girls comprised $46 \%$ of enrolment in Action Aid's community schools in Uganda (Kendi, 2004).

Kenya, the NGOs reflect diversity in their activities from welfare, human rights, gender, agriculture to education. In the education sector, they spent Kshs 890 million in support of various 
education programmes in the year 2006 (Standard; May 18, 2007). In Coast Province, Catholic Relief Services spends Kshs 70 million annually to support over 35,000 orphans and vulnerable children and about 7,000 people living with HIV/ AIDS. In Budalangi district, they support school programmes through provision of uniforms, learning materials, physical facilities and also support capacity development initiatives among teachers. While there is no doubt that NGOs have been instrumental in rural development and that they have had some results in improving access, equity and relevance of primary education, it was necessary to find exactly how they were making their contributions. Needless to say, most of the positive statements of their successes are usually one sided, coming from NGOs themselves. The nature and extent of their support has not been empirically determined through research. IFAD (1998) recommends "that there should be an indepth assessment of their ability to reach the poor, to promote participation and sustainability as well as their own accountability."

\subsection{Purpose of the Study}

The purpose of this study was to determine 
the role of NGOs in supporting public primary education in Budalangi, Kenya.

\subsection{Objectives of the Study}

The objectives of the study are;

1. To determine NGOs participation areas in public primary education focusing on disbursement procedures and equity considerations for different socio-economic groups.

2. To find out the various sources of NGOs funds in the region.

3. To find out the adequacy and relevance of NGOs support to public primary education as perceived by school heads, parents and pupils in the region.

4. To find out the challenges facing NGOs in their effort to support public primary education in Budalangi, Kenya.

\subsection{Research Questions}

This study was guided by five specific research questions: 
1. What forms of support were NGOs giving to public primary school education in Kenya?

2. What are the criteria used by NGOs to identify pupils and schools to support?

3. Who are the main donors of NGOs in the region?

4. Which problems do NGOs encounter in their effort to support public primary education in Kenya?

5. What are the opinions of the parents, pupils and head teachers concerning the adequacy and relevance of NGOs support in Kenya?

\section{Review of Related Literature}

Literature review focused on primary school investment and socio-economic returns, history of public primary education financing in Kenya, and NGOs and primary education investment in Kenya.

\subsection{Primary School Investment and Social- Economic Returns}

As with other human rights, the right to education is an obligation of governments. The constitution provides that every child gets at least 
14 years of basic education at the government's expense (Standard, January 22, 2012). First and most fundamentally, having the skills provided in basic education such as being able to read and write is valuable in it and of it. Education counts as a valuable 'being' or 'doing', as an 'end' of the development sector. Second, the process of education may be instrumental to displacing other negative processes for example compulsory primary education, if it is both provided and enforced, will reduce child labour. Third, empirical studies have indicated that education has a particularly important role in empowerment of the challenged groups including women. Available estimates of rates of return for developing countries constantly show that both private and social returns to primary schooling are higher than at secondary and tertiary levels. Their magnitudes are generally greater than typical returns to capital and economic sectors. A comparison of such rates of return for forty-two countries indicate that average returns to a further year of education across countries are about $10 \%$. However, returns are sharply higher in developing countries than in OECD countries. For instance, the estimated social returns to primary schooling range from $16 \%$ in Asia, Middle East, North America and Latin 
America to about $25 \%$ in Sub-Sahara Africa (UNESCO, 2004).

Various studies by Lockheed and Verspoor (1991), C'clough (1997), Abagi (1997), and Avil (1999) support the UNESCO report that primary education has higher social returns than other levels of education in a barely industrialized country like Kenya. Primary education should therefore receive the highest public investment priority considering its range of benefits.

\subsection{History of Public Primary Education Financing in Kenya}

During the period up to 1963 , colonialists could not provide formal education to the expectations of Africans ostensibly because of lack of money to initiate the expansions needed (Bagonko, 1992).

When Kenya became independent in December 1963, the responsibility of financing education continued to rest on the shoulders of African Districts Councils (Olembo, 1985). In the

1968 Education Act, Chapter 211, the administration of primary education was removed from religious organizations and placed in the 
hands of county councils. The payment of teachers became the responsibility of Teachers' Service Commission which had been formed in 1967. The Ministry of Education retained control over curriculum and inspection of schools while financing and administration was left to local councils which raised funds through local levies and taxes on parents and grants from the Ministry of Education.

In 1971, the government through a presidential decree abolished tuition fees for the poor districts of Marsabit, Isiolo, Lamu, Samburu, Turkana, West Pokot and Tana River. In 1974, another presidential decree provided for free primary education for children in Standard one to four in all districts in Kenya (Olembo, 1985; Bogonko, 1992; Budo, 1985). It further provided a uniform fee for those in Standard five to seven in the whole country. They were to pay Ksh. 60 per year. In 1978, president Moi abolished fees for the remaining three classes so that from January 1979 fees for all the seven classes were abolished (Budo, 1985).

The introduction of Universal Primary Education (UPE) in Kenya, Uganda and Tanzania had more problems than it solved for primary 
education and the society at large (Bogonko, 1992).

The high increase in enrollment led to serious shortage of classrooms, learning facilities and the intensification of teachers' shortage. To cope with the problem, local communities and municipalities were required to erect and maintain physical facilities and grounds. The District Education Boards passed these responsibilities to parents. Such funds plus such other non-fee costs as uniforms, equipment levy and activity fee made primary education more expensive than the pre decree periods. After 1983 general elections, it was declared that parents would have to buy text-books and writing materials for their children as well as equip their schools. By 1998, the government realized the irrationality of assuming the entire burden of education provision and subsequently introduced a cost sharing policy.

A political transition took place in Kenya after the December 2002 elections when an opposition party, the National Rainbow Coalition (NARC) won. In January 2003, the NARC government re-introduced Free Primary Education (FPE). An extra 3.4 million children joined primary education under the initiative with enrolment increasing from 6 million in 2002 to 9.4 million in 
2012 representing an increase of $58.33 \%$. The total expenditure rose from kshs 77.9 billion in $2001 / 2002$ financial year to 140.5 billion in the 2010/2011 financial year. Over the eleven year period, education took over $70 \%$ of the social sector expenditure budget (Government of Kenya: 2011). This shows that the Ministry of Education budget is strained despite the huge increases. More so, the programme largely depends on donors. This raises sustainability questions should the donor's taps run dry as is wont to happen whenever socio-political matters falter. Up to this point, it is evident from the reviews that the government alone could not provide quality education to all eligible children.

2.3 NGOs, and Primary Education Investment in Kenya

NGOs are private organizations either community based (CBO), national or international that contributes to the sustainability and effectiveness of the society. They may be big like OXFAM, CARE, Action Aid, and World Vision or small like self help groups, research institutes, churches, professional organizations or lobby groups (Malena, 1995). Existing literature on NGOs in developing countries especially in Sub-Saharan 
Africa by Malena (1995), Save the Children (1996) and Samboja (2002) reveal that there has been a growing increase in NGOs number, scope, function and financial spending. In Kenya, the civil society has made enormous contributions to national development process. In the education sector, some NGOs assist in solving educational financial constraints. For instance, during the 1980s, the Aga khan Foundation and Save the Children fund equipped eight secondary schools' classrooms with computers (Makau, 2002). Second, some NGOs have spearheaded the development and implementation of a relevant curriculum in new ways. For example, the Undugu Society has been addressing the issue of providing relevant education to destitute urban children.

In a research project that was supported by UNESCO and UNICEF, Ogula and Nguchu, (1993) found out that NGOs were particularly participating in creating partnerships with community groups for the provision of education. Action Aid, KENGO and YMCA mobilize self help groups to promote functional literacy, wood fuel conservation activities and agricultural skills. NGOs also increase the capacity of school children for learning through the provision of health 
services and food, create awareness on the importance of proper hygiene, nutrition and support school feeding programmes. The research further found out that World Vision, Action Aid, Compassion International and Christian Children Fund support literacy by payment of fees, putting up physical facilities like halls, classrooms, workshops, provision of text books and uniforms to the challenged and needy children. In 2006, Action Aid built a secondary school in Budalangi at a cost of kshs. 16 million (Daily Nation July 16, 2006). Kenya Rural Development Programme (KORDP), on the other hand afford the children basic exposure to numeracy and literacy lessons. The organization also creates awareness to the communities on the importance of sending their children to school.

Notwithstanding the enormous contribution of NGOs and civil society organizations (CSOs) in the development process, there are some criticisms leveled on some briefcase NGOs whose conduct and goals are objectionable. Existing literature indicate that corruption, nepotism, authoritarianism and other features of state organizations are now being used to describe some CSOs in Kenya. 
Furthermore, majority tends towards "elitism", they are formed by urban elites quite often for rent-seeking purposes and more so, have intense internal wars among themselves over leadership while some NGOs tend to recruit personnel on ethnic basis.

Poor internal governance is a common feature especially for those managed by individuals (Kobia, 1985; Njuguna, 1989; Samboja, 2002; NGOs council 2004; Nyamu, 2004). Other potential weaknesses include limited managerial and technical capacities, uncertain sustainability, localized operations, limited replicability, limited absorptive capability, and inadequate delivery mechanisms. Resource mobilization is a widespread problem and many NGOs are adept at providing the requisite financial channel and narrative reports to donors, thus raising concern about their accountability, moreover, they are not immune from the problems of financial misappropriation (Fowler, 1990). Constant media reports indicate that the government is suspicious of them. They have been accused of having a hidden agenda. They are said to serve foreigners and their intervention strategies have been questioned. 
In conclusion, in Kenya, the involvement of NGOs in education provision is vital given the inability of the government, communities and parents to meet the challenges of universal primary education provision. The contribution of NGOs as a catalyst of good will, resources and promoters of primary education projects is necessary and should be encouraged. Their contribution is largely appreciated and known in some areas. However not much has been done in some parts of the country. Furthermore, no research has specifically focused on NGOs and public primary education provision especially in rural areas such as Budalangi. Hence we can not be sure of the situation in some parts of the country.

\section{Methodology}

\subsection{Research Design}

In this study, the investigators explored the role of NGOs in financing public primary education in Budalangi, Kenya. The study adopted a descriptive survey design to examine the role of NGOs in a survey, according to Kothari (2003), it is a method of securing information concerning an existing phenomenon from all or a selected number

of respondents of a concerned universe. The study 
was descriptive because it looked at the way things were in terms of NGOs support to public primary education. Survey was also used because there was a systematic collection of data from members of a given population through questionnaires and interviews (Orodho, 2003) which in this case were NGOs administrators, head teachers, parents and supported pupils.

\subsection{Target Population}

The target population comprised of 16 NGOs, 33 public primary schools, 16518 pupils and parents benefiting from NGOs support.

\subsection{Sample Size}

In Budalangi District purposive and simple random sampling was used to select nine NGOs, seven primary schools, 111 pupils and 111 parents giving a total of 238 subjects for the study.

\subsection{Research Instruments}

The study employed questionnaires and interviews to seek information from various sample groups and the data obtained were subjected to descriptive techniques. Questionnaires were used 
to collect data from NGOs' administrators and head teachers while interviews were scheduled for parents and pupils to gather qualitative data. Qualitative techniques were used in the study because they focus on peoples' lives in terms of their idiosyncratic experiences, perspectives, thoughts, behaviors and activities (Clandinin \& Connelly, 2000; Bogdan \& Biklen, 1998) and "examine how people learn and make sense of themselves and others" (Berg, 1998). According to Nasubuga (2000), qualitative data gives the researcher much information and helps them identify significant factors to measure. Using this approach, we encouraged participants to discuss freely their experiences about being beneficiaries of NGOs support towards public primary education in Budalangi, Kenya.

\subsection{Piloting Reliability}

A pilot study was carried out on one NGO, one public primary school, four parents and four pupils receiving support from NGOs in the region to establish the reliability of the research instruments through a test-retest. 


\subsection{Validity}

To validate the research instruments, the researcher used the face validity which is the degree to which the sample of the test items represent the content that the test is designed to measure (Nachiamas \& Nachiamas, 2003). They further point out that in face validity, the relevance of an instrument to the characteristics of the variable it is meant to measure is assessed by face validity.....the researcher's subjective assessment of the instruments appropriateness.... and sampling validity.... the degree to which the statements, questions or indicators constituting the instruments adequately represent the qualities measured.

In this case, face validity was used whereby formulated questions and interview schedules were given to two experts in the Department of Educational Administration, Curriculum and Policy at Kenyatta University to assess their validity and ensure their accurate measurement of what they were supposed to measure. The experts verified and independently validated the research instruments. They made corrections and offered suggestions which were used to make modifications in the questionnaires. 


\subsection{Data Analysis}

Both descriptive and inferential statistics were used to analyze the data. Results from quantitative data were analyzed using simple statistics in the form of arithmetic mean, tables of frequency distributions, and percentages while all the responses from qualitative data were recorded and later transcribed and the transcripts were analyzed for patterns of regularity - that is, categories and themes (Cohen \& Marion, 1994; Clandinin \& Connelly, 2000) and the findings reported. Data was analyzed using Statistical Package for Social Sciences (SPSS) version 16.0 for easy interpretation.

\subsection{Findings}

In this district, it was noted that the number

of supported pupils was significant (31\%) in relation to school enrolment. However NGOs faced a number of challenges in their struggle to support public primary education. 


\subsection{NGOs Participation Areas in Public Primary Education Provision}

a) Forms of Support to Public Primary School Pupils

Provision of school uniforms and psychosocial support took a lion's share with each $26.7 \%$ followed by food (20\%), health (13.3\%), instructional materials (6.7\%) and others (6.6\%) respectively according to NGOs administrators. This was in line with head teachers, parents and pupils responses as shown in table.

Table 1: Comparison of the Kinds of Support NGOs give Pupils as Reported by Parents, Pupils and Head teachers

\begin{tabular}{|l|l|l|l|l|l|l|}
\hline \multicolumn{2}{|l|}{ Forms of support Parents } & \multicolumn{4}{c|}{ Pupils } & \multicolumn{4}{l|}{ Head teachers } \\
\hline & $\mathrm{n}$ & $\%$ & $\mathrm{n}$ & $\%$ & $\mathrm{n}$ & $\%$ \\
\hline Uniforms & 67 & 34.4 & 62 & 36.2 & 6 & 32.0 \\
\hline Medicines & 40 & 20.4 & 29 & 16.9 & 4 & 21.2 \\
\hline Psychosocial & 30 & 15.4 & 25 & 14.6 & 2 & 10.4 \\
\hline Food & 23 & 11.8 & 18 & 10.5 & 2 & 10.4 \\
\hline Beddings & 15 & 7.7 & 16 & 9.4 & 2 & 10.4 \\
\hline Instr. materials & 14 & 7.2 & 16 & 9.6 & 1 & 5.2 \\
\hline Fees & 4 & 2.1 & 3 & 1.8 & 1 & 5.2 \\
\hline Dairy goat & 2 & 1.0 & 2 & 1.2 & 1 & 5.2 \\
\hline Total & & $\mathbf{1 0 0 . 0}$ & & $\mathbf{1 0 0 . 0}$ & & $\mathbf{1 0 0 . 0}$ \\
\hline
\end{tabular}


Research findings from NGOs

administrators, head teachers and pupils revealed that provision of school uniforms was the most (34.2\%) common form of support with each student getting an average of Kshs. 1100 compared to the direct governments support of Ksh 1020 under free primary education while instructional materials and fees were the least (5.2\%) forms of support provided due to FPE. The research further revealed that most parents whose children were supported also were supported. They were provided with medicines, beddings, mosquito nets, shelter, food, dairy goat while some were offered part-time jobs by the supporting NGOs. The findings concur with the findings in the literature review where in coast province, catholic relief services (CRS) spent more than 6 million to provide uniforms to 10,111 orphans in seven Districts (Daily Nation, April 27, 2007).

\section{b) Forms of Support to Primary Schools}

Apart from the support to pupils and parents, most (36.4\%) NGOs studied concentrated on the provision of physical facilities (33.4\%). Other forms of support to primary schools included provision of equipment (21.9\%), instructional 
materials (18.2\%) and teachers' provision and others $(11.4 \%)$ respectively.

These findings were similar to those in the literature where NGOs such as the Agakhan Foundation, Save the Children, Action Aid (K) and CARE International assisted in solving educational financial constraints. For instance, the Agan Khan Foundation and Save the Children Fund equipped eight secondary classrooms with computers (Makau, 2002). UNICEF and FAO support NGOs that try to enhance health and nutrition of preprimary and primary school children particularly in drought stricken and impoverished areas (Woka, 2003).

\subsection{Criteria and Methods used by NGOs to Identify Pupils}

All NGOs were found to support pupils that were orphans, poor and needy. Families of supported pupils lived in abject poverty and their standards of living were very low. This was depicted in their occupations, income and the type of houses they lived in. Most (80\%) parents had no or low income occupations and lived in mud or makeshift houses. The number of supported girls 
was however more or equal to boys. This showed NGOs' aim to reduce poverty and gender disparities in the provision of public primary education as was reported in the literature review and background to the study.

The research further found out that NGOs identify and select pupils and projects to support by conducting field visits and sometimes done with the help of head teachers, parents, local administrator and village representatives while in some cases pupils, parents or even head teachers visited or wrote letters to NGOs seeking support.

\subsection{Sources of NGO Funds}

It importantly emerged that most (43.8\%) NGOs relied on international donors for funds. This over-reliance on international donors for funding was found to be risky to the projects supported by NGOs because should the donors' taps run dry, then most projects would collapse. Regarding how much was spent on education programmes in the year 2008, most NGOs (88\%) were reluctant and did not respond to this question. This is in line with the research findings in the background study that few NGOs are adept on providing the requisite 
financial reports thus raising concern about their accountability.

\subsection{Challenges and Problems Encountered}

a) Emerging Trends

With regard to emerging trends of support to primary school education, it was found from the NGOs that there was a decline in support. This raised sustainability questions as most (71\%) parents said that they had not been prepared incase NGOs exit. Most (63\%) projects supported would continue at a low pace or stall altogether.

b) Challenges Encountered by NGOs

The research showed that most (58.3\%) NGOs mentioned insufficient funds. Some (16.7\%) stated lack of cooperation from parents and high increase in the number of widows and orphans.

c) Problems Encountered by Primary Schools

The head teachers experienced quite a number of problems. The main ones were: 
i) Lack of cooperation or mistrust from parents. Most head teachers complained of suspicion as some parents felt that they were benefiting a lot through their children. Some pupils dropped out of school despite getting support from NGOs.

ii) Head teachers complained that in some cases they were not consulted before the projects were approved for the concerned NGOs.

iii) Lack of cooperation from NGOs as some NGOs did not disclose to the head teachers the assistance they were giving to pupils in their schools. This raised credibility questions.

iv) There was lack of continuity as some projects stalled due to insufficient funds.

v) Interference with learning programmes as NGOs collected information from pupils sometimes during the learning sessions.

d) Problems Encountered by Parents 
i) No guaranteed support. In some cases parents had to regularly apply for support and at times they were forced to keep their children at home when the support was not forthcoming.

ii) The support was not enough and did not come in time. Sometimes the support meant for one pupil in the family was shared by other family members.

iii) In some cases parents were not allowed to deal with their sponsors from abroad directly as the support had to pass through the local NGO.

iv) Some parents mentioned that the support given to their children was irrelevant as they were not consulted.

v) Some times the very needy were left out.

e) Problems Encountered by Pupils

i) Pupils identified lack of enough text books, uniforms, food, shelter and 
tuition fees.

ii) Pupils indicated that whatever they got was inadequate and inconsistent and sometimes irrelevant.

iii) NGO agents demanded a portion of the support delivered.

\subsection{Participants' Perceptions on the Adequacy and Relevance of NGOs' Support}

All the respondents indicated that the support was inadequate. This was as a result of insufficient funds and the high number of orphans and widows. To ensure that the support given reached the beneficiaries, all NGOs used monitoring and evaluation. All the respondents were contented with the support they got since it was reportedly relevant.

Participants' Suggestions for Improving NGOs Support

a) Suggestions from Head Teachers

i) Increase in NGOs support but with modification on the way provisions were made. 
ii) More support for physical infrastructure as this was seen to be very expensive and out of reach of most parents.

iii) More support for the ever increasing number of orphans.

iv) NGOs to consider other areas such as school feeding programmes, educational trips, school fencing, and installation of electricity.

b) Suggestions from Parents

i) NGOs should start income generation projects to ensure continuity of support.

ii) NGOs should address the issue of teachers' shortage to enable children get quality education.

iii) Provision of physical facilities.

iv) Support school feeding programmes.

v) Payment of tuition fees, shelter and provision of farm inputs. 
c) Suggestion from Pupils

Most (37\%) pupils mentioned the need to provide more text books while another (18\%) required additional uniforms urgently. The remaining percentage mentioned fees (15\%), food (6\%), and medication (2\%).

\section{Recommendations}

In view of the above findings, we recommend the following:

i) The NGOs should increase their support towards public primary education so as to help the increasing number of the poor, needy and vulnerable children and where possible use capacity building to guarantee sustainability of the supported projects.

ii) Parents complained that some support did not reach them in full. The NGOs should therefore consider the use of electronic funds transfer system to channel their resources to both schools and parents and encourage parental support for education. 
iii) NGOs should start income generating projects with part of the money that they receive from the donors to help sustain their projects as over-reliance on international donors is very risky because should the donors' taps run dry, then most of their projects would collapse. This would help reduce the problem of insufficient funds.

iv) Since NGOs have great potential in the mobilization of resources for primary education, the government needs to further network with them and create an enabling environment to encourage private investment in education. This could be done through formulating task rebate policies, creating awareness to the public on the importance of NGOs and giving professional support to such NGOs. 


\section{References}

Abagi, O. (1997). Public and private investment in primary education in Kenya: "An agenda for action". Nairobi: Institute of Policy Analysis and Research (IPAR).

Avil, V. A., \& Harnet, T. (1999). Cost- sharing in the social sectors of sub-Saharan Africa. Impact on the Poor. Washington D.C: World Bank.

Berg, L.B. (1998). Qualitative research methods for the social sciences. Boston: Allyn \& Bacon.

Bogdan, R. C., \& Biklen, S. K. (1998). Qualitative research in rducation. An introduction to theory and methods. Boston, MA: Allyn \& Bacon.

Bogonko, S. (1992). A history of education in Kenya. London: Evans Brothers Ltd.

Bogonko, S. (1992). Reflections on education in East Africa. Nairobi: Oxford University Press.

Budo, other name? (1985). Primary schools, local community and development in Africa. City? Baden Baden.

Clandinin, D. J. \& Connelly, F. M. (2000). Narrative inquiry, experience and story in qualitative research. San Francisco, CA: Jossey-Boss Publishers. 
Cohen, L. and Marion, other name? (1994). Research methods in education (4th $\mathrm{ed}$.). London: Routledge Ltd.

C 'Olough, C. (1997). "Aid to basic education in Africa. Opportunities and constraints". Anannual report 5: 97. USA: The Royal Ministry of Foreign Affairs.

Fowler, A. (2002). "The role of NGOs in changing state: Society relations: perspectives from East and Southern Africa". Development Policy Review 9(1), 53-84.

Gituai, P. (2007, May 18). NGOs as partners in education. East African Standard, p.25.

Government of Kenya. (2011). "Economic survey 2011". Nairobi: Government Printers.

Government of Kenya. (2002). Busia District development plan 2002-2008. Nairobi: GoveRment Printers.

Haddad, W. (1990). "World conference on education for all", Meeting basic learning needs, 5-9 March 1990, Jomtiem, Thailand Final Report USA Inter-Agency Commission. Paris: UNESCO.

IFAD. (1992). Meeting Challenges in a changing World. Rome: Christen Graf.

Kagia, R. (1986). Education child survival and development in Africa. Paris: UNESCO/UNICEF.

Kendi, J. (2003). An investigation into the human resource training. A study of human rights NGOs in Kenya (Unpublished Med Thesis). Kenyatta University. 
Kobia, S. (1985). "The Old and New Approaches to Development". Nairobi: Institute of Development Studies.

Kokul, R. (1991). Maternal and child health in Kenya. City? The Finish Society for Development Studies and the Scandinavian Institute of Development Studies.

Kothari, C. R. (2003). Research methodology: Methods and techniques. New Delphi: Vishwa Prakashan.

Lockheed, M. E and Verspoor, A. (1991). Improving Primary Education in Developing Countries. World Bank, Washington DC: Oxford University Press.

Makau, B. (2002). Dynamics of partnerships in provision of general education in Kenya. Nairobi: EAP.

Malena, C. (1995). Working with NGOs. Washington DC: World Bank.

Nachiamas, C. F. \& Nachiamas, D. (2003). Research Method in Social Sciences (5 ${ }^{\text {th }}$ ed.). London: St. Martin's Press Inc.

Nasubuga, E. H. K. (2000). Fundamentals of educational research. Kampala: MK Publishers.

National Council of NGOs. (2004). Civil society in the third republic. Nairobi: Print Option.

Njuguna, N. (1989). In search of NGOs: Towards a funding strategy to create $N G O$ research capacity in Eastern and Southern Africa. Nairobi: Institute of Development Studies. 
Nyamu, I. K. (2004). An investigation into human resource training practices. A case of human rights NGOs in Nairobi (Unpublished Med Thesis). Kenyatta University.

OECD. (1996). Shaping the 21st Century: The contribution of development co-operation, Development Assistance Committees. Paris: OECD.

OECD. (1999). Non-Governmental organizations in World Bank supported projects. Washington, DC: World Bank.

Ongeri, O. (2012, January 18). Affordable quality and relevant education. East African Standard, p. 36.

Ole Kiyiapi, J. (2012, January 22). Education is a human right. Nairobi. Standard Newspaper, p. 28.

Olembo, J. O. (1985). Financing primary schools buildings in Nairobi-Kenya. Nairobi: Transafrica Press.

Orodho, J. A. (2003). Elements of education and social science research methods. Nairobi: Masola Publishers

Saitoti, G. (2007, April 27). Shillings three billion spent on free learning so far. Nairobi. Daily Nation, p. 4.

Samboja, J. and Ole, J. (2002). Service provision under stress in East Africa. The state, NGOs and peoples organizations in Kenya, Tanzania and Uganda. Nairobi: EAP.

Save the Children. (1996). NGOs performance and accountability. London: Earthscan Publishers.

Sifuna, D.N. (2000, March 11). "Why education for all has remained a mirage." Nairobi. Standard Newspaper, p. 4. 
Tuckman, Bruce, W. (1972). Conducting educational research. New York:. Harcourt Brace Jovanovich.

UNESCO. (2003-04). Education for all global monitoring report. Gender and education for all. Paris: UNESCO.

Wachira, K. (2013, February 27). Laptops or good classrooms: What's the pupils' priority need? Nairobi. Standard Newspaper, p.32.

Wanjala, R. B. (2006, July 16). Action aid builds a school at the cost of 16 million. Nairobi. The Daily Nation, p.21.

Woka, G. D. (2003). Role of NGOs in the provision of public primary education in Nairobi Unpublished Med Thesis). Kenyatta University.

World Bank. (1990). Primary education policy paper. Washington D.C.: World Bank. 